doi: 10.19090/i.2021.32.100-115

UDC: 930.85

\author{
АРТЕМ МАСЛОВ \\ Нижегородский государственный университет им. Н.И. Лобачевского \\ Кафедра истории древнего мира и средних веков \\ maslovartem@yandex.ru
}

\title{
ГРАД ЦАРЯ ПРИАМА И РУССКАЯ «ЦАРЬ-КНИГА»: ОПИСАНИЯ ДРЕВНЕЙ ТРОИ В «ЛИЦЕВОМ ЛЕТОПИСНОМ СВОДЕ ИВАНА ГРОЗНОГО॥*
}

\begin{abstract}
Аннотация: Статья продолжает серию исследований по вопросам репрезентации городских пространств античности в литературной традиции Средневековья и посвящена анализу фрагментов «Лицевого летописного свода» (ЛЛС), в которых описывается строительство легендарной Трои по приказу царя Приама. Первое из этих описаний приведено в составе древнерусского перевода «Троянской истории» Гвидо делле Колонне (Гвидо де Колумна) и подробно освещает внешний и внутренний облик древнего города, особенности его заселения и занятия горожан. Такой «рациональный» подход, связанный с дидактическими компонентами латинской «Истории» Гвидо и отчасти сохраненный в древнерусской традиции, вступает в противоречие с картиной строительства Трои, которая содержится во втором произведении на троянскую тему в составе ЛЛС - «Повести о создании и попленении Тройском». Последняя является переработкой южнославянской «Притчи о кралех» и, в отличие от «Троянской истории», характеризуется акцентом на мифологических (или даже демонических, согласно христианской трактовке этого эпизода) истоках Приамовой Трои. Нестандартным - в свете бытования латинского текста «Истории» на Западе представляется ее фактическое объединение с текстом «Повести» на страницах ЛЛС. Определенная этим обстоятельством двойственность репрезентации величайшего города древности рассматривается автором в связи с общей проблематикой средневековой рецепции троянских легенд на Западе и Востоке Европы. Особое внимание уделено миниатюрам, которые иллюстрируют в ЛЛС соответствующие эпизоды повествований и могут включать в себя ряд визуальных кодов, моделирующих восприятие изображений читателем.

Ключевые слова: образы Трои в средневековой традиции, «История разрушения Трои» Гвидо делле Колонне (Гвидо де Колумна), древнерусский перевод, «Лицевой летописный свод Ивана Грозного», «Повесть о создании и попленении Тройском».
\end{abstract}

* Работа выполнена при поддержке гранта РНФ, проект № 20-18-00374 «Имперское Средиземноморье: модели, дискурсы и практики империализма от Античности до раннего Нового времени». 
Б ытование в позднесредневековой Руси переводов латинской литературы об античности и, в частности, о Троянской войне - интересный сюжет для кросскультурных исследований и сравнительного изучения образов древности на Западе и Востоке европейского континента. Несмотря на имеющиеся научные труды по этой теме ${ }^{1}$, многие ее аспекты еще недостаточно проработаны. Обращение к ним сулит более точные знания и о конкретных обстоятельствах переводческой деятельности русских книжников, и об общем интеллектуальном контексте, в котором разворачивалась адаптация инокультурного материала к запросам новой читательской аудитории. В настоящей статье мы хотели бы приблизиться к пониманию того, как транслировался в древнерусской традиции пассаж «Троянской истории» Гвидо делле Колонне $(1287 \text { г. })^{2}$ о сооружении царем Приамом великой Трои ${ }^{3}$ (на месте предшествующего ей города, разрушенного греками во главе с Ясоном и Геркулесом).

Стоит пояснить, что сопоставление данного фрагмента «Истории» Гвидо с соответствующими сведениями «Романа о Трое» (1160-е гг.) Бенуа де Сент-Мора, ранее позволило нам выявить весьма существенные расхождения в репрезентации городского пространства двумя этими авторами ${ }^{4}$. Перерабатывая старофранцузскую поэму Бенуа латинской прозой, Гвидо привнес в образ восстановленной Трои ряд важных деталей, незнакомых его предшественнику. Так, великолепие заново возводимого Приамом города было связано для Гвидо, в первую очередь, с расцветом ремесел и торговли, многочисленностью собственно трудящегося населения. Внутригородское пространство великой Трои в латинской «Истории» ранжировалось с учетом не только военных вызовов, но и природных условий. Изобретенные здесь развлечения подразумевали зрелищность и наличие широкой аудитории, а равно специфической локализации. Вводимая же Гвидо аналогия между реками Ксанфом и Тибром помогала высветить как родство троянцев и римлян, так и адекватный его писательскому замыслу «антикизирующий» кадр урбанистических фантазий. Сделанные Гвидо делле Колонне акценты позднее были развиты другими западными авторами, которые пересказывали «Историю» в XIV-XV вв. Любопытно разобраться, в какой мере интересующее нас описание было понято и принято в русской традиции.

Основным объектом наблюдения в данном случае выступает наиболее ранний Музейский список т.н. Древнейшей редакции древнерусского перевода ${ }^{5}$ «Истории»

\footnotetext{
Наиболее важной публикацией уже почти полвека остается научное издание «Троянские сказания: Средневековые рыцарские романы о Троянской войне по русским рукописям XVI-XVII веков», подготовленное О.В. Твороговым при участии М.Н. Ботвинника - см. Tvorogov 1972. Отдельные аспекты темы разрабатывались также И.Ю. Серовой, В.Ф. Хрипковым, Д.М. Буланиным, Т.Ф. Волковой: Serova 1989; Bulanin 1993; Khripkov 1993; Volkova 2004. В качестве небольших обзорных статей последних лет укажем: Maslov 2010; Bushkovitch 2020.

2 В латинских рукописях сочинение Гвидо делле Колонне (Гвидо де Колумна) выступает под названиями «История разрушения Трои» (“Нistoria destructionis Troiae”), «Троянская история» (“Нistoria Troiana”), «Книга о падении Трои» (“Liber de casu Troiae”) и др.. В специальной литературе оно чаще фигурирует под первым названием. См. критическое издание латинского текста: Griffin 1936.

Ibid.: 46-50.

Maslov 2019.

О времени и предполагаемых обстоятельствах перевода «Истории» Гвидо, его редакциях и истории изучения см.: Tvorogov 1972: 153-159, 166-184. В этом же издании (стр. 14-69) опубликован текст
} 
Гвидо, являющийся частью знаменитого книжного памятника - «Лицевого летописного свода Ивана Грозного» (далее - ЛЛС) ${ }^{6}$ второй половины XVI в. ${ }^{7}$ Главной особенностью этой версии перевода «Истории» можно считать то, что именно в составе ЛЛС ${ }^{8}$ рассказ Гвидо обрел (насколько нам известно, лишь однажды в древнерусской книжности) и характерное иконографическое воплощение: миниатюры, иллюстрирующие повествование о Трое, также могут проливать свет на специфику восприятия легендарного города древности в позднесредневековом русском контексте. Кроме того, сам факт инкорпорации перевода пространной «Истории» (воспринимавшейся на Западе как вполне авторитетное - и опосредованное личным вкладом известного писателя - сочинение) в сводный труд9, который охватывал самые разные периоды прошлого и подчас контаминировал различные в жанровом плане свидетельства, служит важным маркером специфического прочтения троянской темы русской аудиторией XVI столетия.

Отдельно оговорим тот факт, что проведенное нами сравнение носит сугубо предварительный характер и никоим образом не может претендовать на роль комплексного исследования Древнейшей редакции перевода «Истории» Гвидо. Такой всесторонний анализ предполагал бы тщательное сличение версии из Музейского сборника с другими списками указанной редакции - в первую очередь, с Уваровским (вт. пол. XVII в.), который, несмотря на позднюю датировку, являет собой, по мнению О.В. Творогова ${ }^{10}$, наиболее исправный вариант древнерусского перевода «Истории». Вместе с тем, обозначенная выше нетривиальность вхождения интересующей нас версии в состав монументальной иллюстрированной компиляции ЛЛС, обусловила обращение именно к этому памятнику - благо, текстологическая сторона представленной работы на данный момент не является основной и, очевидно, еще будет скорректирована в дальнейшем.

Воплощая собой традицию пословного (буквального) перевода, характерную для древнерусской словесности, интересующая нас «Троянская история» была довольно близка к латинскому оригиналу в плане сохранения лексической и грамматической информации (чего порой нельзя сказать о смысле синтаксических

Краткой редакции (по списку второй четверти XVII в.) и его перевод на современный русский язык (стр. 78-136). Первые три книги Древнейшей редакции по Уваровскому списку (Государственный исторический музей, собр. Уварова, № 525 (1310)) опубликованы О.В. Твороговым в восьмом томе «Библиотеки литературы Древней Руси» - см.: Likhachev et al. 2003: 152-193.

6 При подготовке статьи мы пользовались электронной версией факсимильного издания, осуществленного издательством «Актеон». Все ссылки на листы рукописи далее сопровождаются указаниями на страницы того или иного тома данного издания.

7 Истории создания и бытования Лицевого летописного свода посвящена обширная литература. См. в качестве наиболее важных обобщающих работ: Amosov 1998; Shmidt et al. 2003; Morozov 2005.

8 Музейский сборник, включивший рассматриваемый нами список, представляет собой первый том ЛЛС. См. кодикологическое описание Музейского сборника: LLS. Vsem. Ist. ST: 20-23.

9 Отдельные версии латинской «Истории» Гвидо могли включаться в состав компилятивных сочинений и на Западе. Однако там речь, как правило, идет о сильно сокращенных адаптациях.

10 Tvorogov 1972: 169. 
оборотов или предложений в целом $)^{11}$. Фрагмент, содержащий описание Трои, не является здесь исключением. В целом, древнерусская версия, представленная в рассматриваемом далее Музейском списке, более-менее точно следует за повествованием Гвидо, транслируя большинство упомянутых латинским автором деталей. Судить о близости исходного и переводного текста можно с опорой на приведенные ниже отрывки.

\begin{tabular}{|c|c|c|}
\hline $\begin{array}{c}\text { Латинский текст 'Historia } \\
\text { destructionis Troiae’ по } \\
\text { изданию Гриффина }\end{array}$ & $\begin{array}{c}\text { Перевод с латинского на } \\
\text { современный русский язык }\end{array}$ & $\begin{array}{c}\text { Музейский список (ОР ГИМ, } \\
\text { Музейское собрание, № 358), } \\
\text { л. 618об- } 619^{14}\end{array}$ \\
\hline $\begin{array}{l}\text { Fuit autem huius secunde Troye } \\
\text { ambitus longitudinis trium dierum } \\
\text { et latitudinis coequalis. Nec ante } \\
\text { fundationem eius aut postea } \\
\text { nunquam legitur condita ciuitas } \\
\text { tante magnitudinis, tante } \\
\text { pulcritudinis, aut similis speciei. } \\
\text { Fuerunt etenim fundamenta eius in } \\
\text { terre gremio constituta, multum } \\
\text { profunda facta scissura et latitudine } \\
\text { spatiosa. A terre igitur superficie } \\
\text { usque ad summum eius } \\
\text { superhedificata sunt menia in } \\
\text { mirabili compositione murorum } \\
\text { circumquaque cubitorum altitudine } \\
\text { ducentorum, quorum superficies } \\
\text { erat marmoreis incrustata lapidibus } \\
\text { in uariorum diuersitate colorum ut } \\
\text { intuentium aspectibus blandirentur. } \\
\text { In murorum itaque ipsorum } \\
\text { circumgiratione corone non } \\
\text { multum vna turris distabat ab alia } \\
\text { que supra muros eosdem } \\
\text { excrescenti altitudine imminebant. }\end{array}$ & 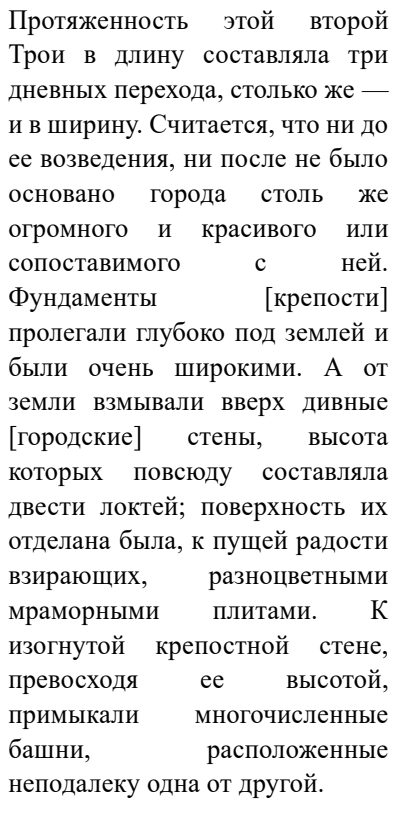 & 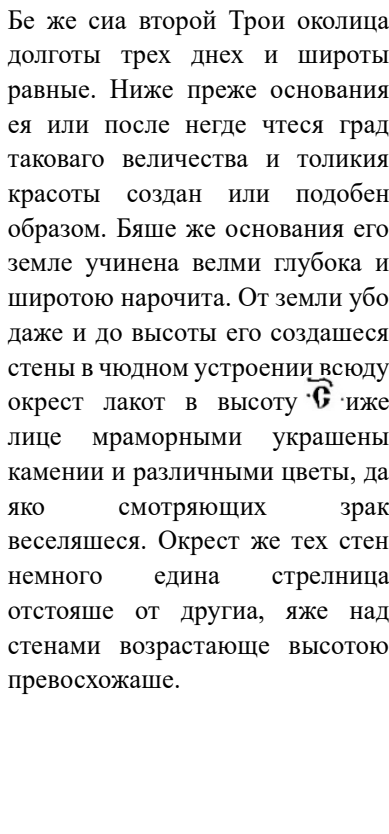 \\
\hline
\end{tabular}

Таблица 1. Описания крепостных стен и башен Трои

11 См. по этому поводу: Tvorogov 1972: 188-190.

12 Griffin 1936: 46-47. Среди специалистов утвердилось мнение, что первоначальный текст древнерусского перевода «Истории» Гвидо был выполнен по одному из страсбургских изданий 1480 х гг. Используя фрагменты критического издания Н.Э. Гриффина, мы сверяли их с соответствующими отрывками страсбургских изданий 1485, 1486, 1489 и 1494 гг., но не выявили разночтений.

13 Здесь и далее переводы латинского текста «Истории» на современный русский язык выполнены автором статьи.

14 LLS. Vsem. Ist. Kn. 1: 125-126. Здесь и далее нами используется транслитерация древнерусского текста, выполненная М.М. Панковой и Е.Н. Казаковой. 
Трудности с пониманием возникали там, где Гвидо начинал оперировать названиями - знакомыми для образованного западного читателя, но не особо привычными для русских книжников - или использовал слова с неочевидными смыслами (ср. лат. hiatus / hyatus в значении «ловушка»):

\begin{tabular}{|c|c|c|}
\hline $\begin{array}{c}\text { Латинский текст 'Historia } \\
\text { destructionis Troiae’ по } \\
\text { изданию Гриффина }\end{array}$ & $\begin{array}{c}\text { Перевод с латинского на } \\
\text { современный русский язык }\end{array}$ & $\begin{array}{c}\text { Музейский список (ОР ГИМ, } \\
\text { Музейское собрание, № 358), } \\
\text { л. 619-619об }^{16}\end{array}$ \\
\hline $\begin{array}{l}\text { Introitus autem et exitus ciuitatis } \\
\text { ipsius fuit in sex ianuis institutus, } \\
\text { quarum una Dardanides, secunda } \\
\text { Tymbrea, tercia Helias, quarta } \\
\text { seca, quinta Troyana, et sexta } \\
\text { Anthenorides vocabantur. Quelibet } \\
\text { portarum ipsarum bellicosis fuerat } \\
\text { firmata turribus per latera et in } \\
\text { celaturis marmorearum imaginum } \\
\text { circumquaque decora. Quarum } \\
\text { quelibet amicis intrare uolentibus } \\
\text { placidos permittebat ingressus et } \\
\text { superbe resistentie quibuslibet } \\
\text { inimicis duros et fortes minabatur } \\
\text { accessus. Erant etiam ipsi muri ex } \\
\text { exteriori parte per ambitus } \\
\text { circumquaque obscuris hyatibus } \\
\text { profundo uallo firmati, cuius ualli } \\
\text { distantia inter se et muros eosdem } \\
\text { longa planicies extendebat. }\end{array}$ & 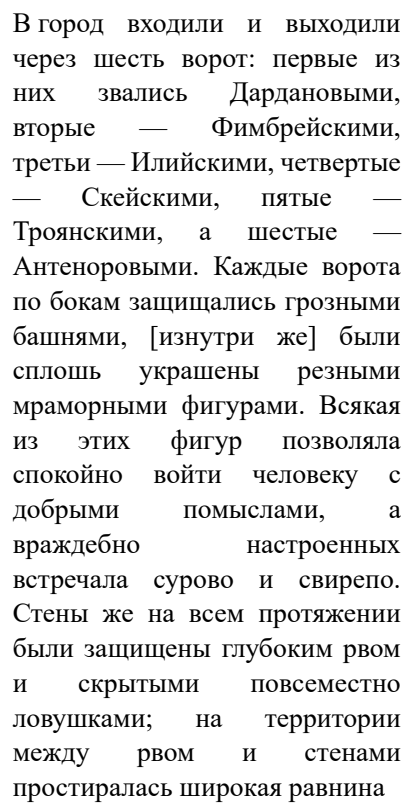 & $\begin{array}{l}\text { Вход же и исход града того } \\
\text { шестию враты устроен. Их же } \\
\text { первые Даръдинидес, вторые - } \\
\text { Тембрея, третьие - Елеяс, } \\
\text { четвертые }- \text { Тетас, пятыя } \\
\text { Трояны, а шестые } \\
\text { Антоноридес } \\
\text { Каяждо бо врат тех бранными } \\
\text { беша стрелницами укреплена по } \\
\text { странам и резию мраморных } \\
\text { образов всюду окрест украшена. } \\
\text { Их же коижо другом внити } \\
\text { хотяшиим - любезныя даваше } \\
\text { входы, и гордаго противления } \\
\text { коимождо врагом - жестокие и } \\
\text { крепкие прещаше приходы. Беша } \\
\text { паки стены от внешнии окрест } \\
\text { всюду тайными темными и } \\
\text { глубокими рвы утверженны. Его } \\
\text { же рва разстояние промеж себе и } \\
\text { стен долгою площадию } \\
\text { протязашеся. }\end{array}$ \\
\hline
\end{tabular}

Таблица 2. Описания городских ворот Трои

Не вполне прозрачными оказывались и те отрывки, в которых Гвидо пытался соотнести градостроительные решения создателей Трои с природными условиями. В следующей таблице курсивом выделены те фрагменты древнерусского текста, которые, по-видимому, неадекватно передают смысл оригинала.

\footnotetext{
15 Griffin 1936: 47.

16 LLS. Vsem. Ist. Kn. 1: 127-128.
} 


\begin{tabular}{|c|c|c|}
\hline $\begin{array}{c}\text { Латинский текст "Historia } \\
\text { destructionis Troiae" по } \\
\text { изданию Гриффина } \\
\end{array}$ & $\begin{array}{c}\text { Перевод с латинского на } \\
\text { современный русский язык }\end{array}$ & $\begin{array}{c}\text { Музейский список (ОР ГИМ, } \\
\text { Музейское собрание, № 358), } \\
\text { л. 619об-620об }\end{array}$ \\
\hline $\begin{array}{l}\text { Infra uero ciuitatem eandem } \\
\text { instructa fuerunt infinita palatia et } \\
\text { in ea infinite domus ciuium } \\
\text { formosis hedificiis fabricate, que } \\
\text { ciuitatem eandem ornabant in } \\
\text { multarum latitudine platearum. } \\
\text { Pro certo enim asserunt nullam } \\
\text { domum, nullum hospicium in } \\
\text { ciuitate Troye fuisse constructum } \\
\text { cuius illud quod minoris } \\
\text { depressionis extiterat supra terram } \\
\text { saltem erectum in lx cubitorum } \\
\text { altitudine non fuisset, totum etiam } \\
\text { marmoreis firmatum lapidibus in } \\
\text { mirificis ymaginum ferarum et } \\
\text { hominum celaturis. Erant et eius } \\
\text { platee longo et recto distense } \\
\text { dyametro, in quarum medio } \\
\text { disco }<\text { }>\text { pertus aer uegetabilis } \\
\text { aurore dulces et uarios refundebat } \\
\text { afflatus. In ipsarum uero lateribus } \\
\text { platearum innumerabilibus super } \\
\text { columpnis marmoreis arcubus } \\
\text { circumuolutis erectis, sub ipsorum } \\
\text { hedificiis eleuatis, liber et } \\
\text { cotidianus gradientibus patebat } \\
\text { incessus ut nec a uentorum rabie } \\
\text { nec ab ymbrium rore celesti } \\
\text { uexarentur inuitis aspersionibus } \\
\text { gradientes. }\end{array}$ & 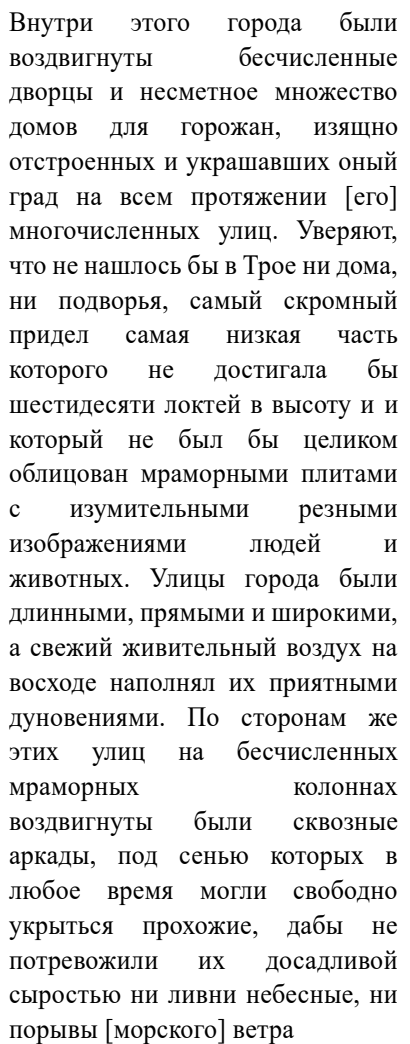 & $\begin{array}{l}\text { Внутрь же града того } \\
\text { сооруженна беша безчисленныя } \\
\text { полаты и безсконечные домы } \\
\text { градцкие, добро различными и } \\
\text { здании соделанный же град он } \\
\text { украшаху, в широту многих } \\
\text { улиц. За истинну убо глаголют: } \\
\text { ни един дом, ни единого } \\
\text { гостинница во граде Трои бе } \\
\text { соруженны, ея же наименгее } \\
\text { здание бе возставлено в за } \\
\text { лакот в высоту, все паки } \\
\text { мраморными камении } \\
\text { утвержено, с чюдною образов } \\
\text { звериных и человеческих резию. } \\
\text { И беша улицы долги и прямо } \\
\text { протягновенны, посреди же их } \\
\text { откровенные аер жсивотные } \\
\text { зори и сладкие и разные } \\
\text { изливаше дохновени. По } \\
\text { странам же техулиц безчислении } \\
\text { столпи и мраморных кругов } \\
\text { изетием поставлены и на[д] } \\
\text { зданием тех вознесены. По ним } \\
\text { же сице свободно и вседневно } \\
\text { хотящим даваше прихожение, да } \\
\text { ниже ветреною бурею, ниже от } \\
\text { дождевные росы небесные } \\
\text { утружахуся хотящеи. }\end{array}$ \\
\hline
\end{tabular}

Таблица 3. Описания внутригородского пространства Трои

Самые частые расхождения можно наблюдать в обширном перечне троянских ремесленников и торговцев, который приведен в «Истории». Этот перечень (не имеющий, к слову, аналогов в «Романе о Трое»), скорее всего, был очень важен для латинского писателя XIII в., помогая ему в известной степени «приземлить» и демистифицировать облик легендарной Трои. Появление великого города, истинным создателям которого, французский поэт XII в. почти не уделил внимания, для Гвидо очевидным образом соотносилось с расцветом здесь ремесел и многочисленностью мастеровых людей («каталогизируя» которых, автор не преминул обратиться к излюбленной для него правовой традиции - часть перечня, как было показано нами ранее, Гвидо заимствовал

\footnotetext{
Griffin 1936: 47.

18 LLS. Vsem. Ist. Kn. 1: 128-130.
} 
из «Кодекса Юстининана» ${ }^{19}$ ). Попытаемся определить, насколько точно данный фрагмент передан в исследуемом списке Древнейшей редакции:

\begin{tabular}{|c|c|c|}
\hline $\begin{array}{c}\text { Латинский текст 'Historia } \\
\text { destructionis Troiae’ по } \\
\text { изданию Гриффина } \\
\end{array}$ & $\begin{array}{c}\text { Перевод с латинского на } \\
\text { современный русский язык }\end{array}$ & $\begin{array}{c}\text { Музейский список (ОР ГИМ, } \\
\text { Музейское собрание, № 358), } \\
\text { л. 620об }{ }^{21} \\
\end{array}$ \\
\hline $\begin{array}{l}\text { Per plateas enim ipsas mechanicarum } \\
\text { artium locate fuerunt proprie stationes, } \\
\text { in quibus earum operarii, per certa loca } \\
\text { distincti, cotidianis operibus et } \\
\text { uenalibus artificiis insudabant. Hic } \\
\text { enim architecti manebant, hic pictores, } \\
\text { hic statuarii, hic marmorarii, hic } \\
\text { le }<\text { c }>\text { ticarii manebant; hic } \\
\text { canicularii, hic quadrigarii, hic } \\
\text { lig }<\text { n }>\text { arii, hic mularii, hic } \\
\text { deauratores albini, qui statuas et } \\
\text { ymagines in auro pingebant, hic } \\
\text { argentarii, hic dyatretarii, qui calices } \\
\text { conficiebant ex uitro, hic er[r]arii, hic } \\
\text { fusores, qui campanas ex metallo } \\
\text { fundebant, hic signarii, qui sigilla } \\
\text { formabant, hic fabricarii, qui } \\
\underline{\text { camiscias suebant et bracas, hic }} \\
\text { fusarii, qui ferreo inferro fusos } \\
\text { extenuant muliebres, hic perticarii, hic } \\
\text { libratores, hic figuli, hic aurifices, hic } \\
\text { plumbarii, hic specularii, hic pelliparii, } \\
\text { hic fulones, hic carpentarii, hic } \\
\text { tignarii, qui uehicula scilicet rotis } \\
\underline{\text { uolubilibus sociabant, hic dealbatores }} \\
\text { armorum, hic balthearii, seu } \\
\text { pantalarge qui opus deaurati eris in } \\
\underline{\text { frenis apponunt, hic classicularii, hic }} \\
\text { fabricenses, hic gineciarii, qui textores } \\
\text { appellantur, hic geometre, qui iugera } \\
\text { rusticarum terrarum numero } \\
\text { diuidebant, hic baphi, qui pannos } \\
\text { lineos et laneos in multo colore } \\
\underline{\text { tingebant, hic pistores, hic tabernarii, }} \\
\text { hic cerarii, hic arilatores, quos } \\
\underline{\text { mercatores uulgariter appellamus, hic }} \\
\underline{\text { argiroprate, id est distractores argenti, }} \\
\text { hic et alii plures qui venales artes } \\
\text { mechanicas exercebant. }\end{array}$ & 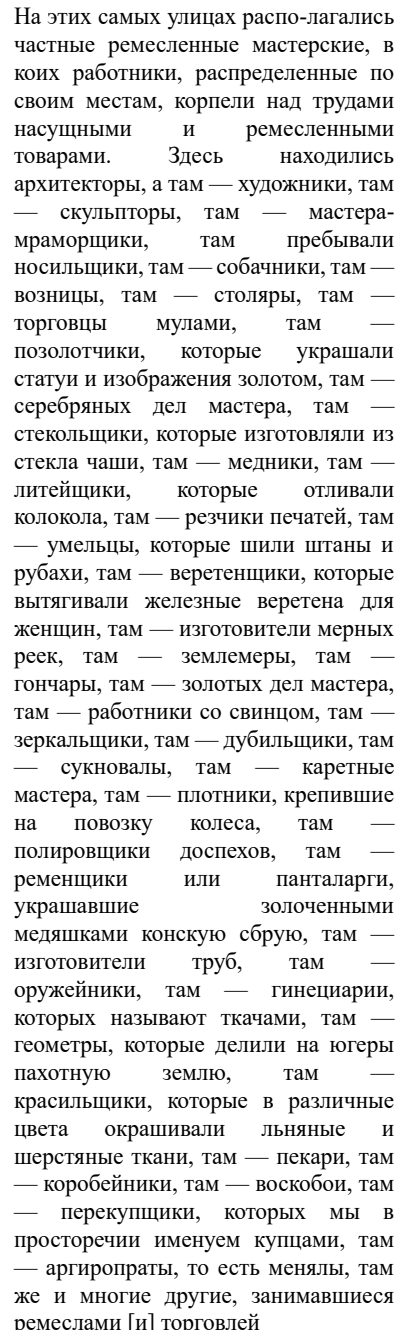 & $\begin{array}{l}\text { По улицам и убо тем рукодел-ных } \\
\text { хитростей учинены беша свои места, } \\
\text { в них же их делатели по особным } \\
\text { местом разделены в седневных делех } \\
\text { и хитростех продаемых тружахуся. } \\
\text { Ово убо архиздатели пребываху, ово } \\
\text { иконописцы, ово образорезцы, ово } \\
\text { же мраморникы, ово ложеделателие, } \\
\text { ово юзники, колесники, ово } \\
\text { ременопродавиы, ово левкасники, } \\
\text { иже образы на злате писаху, ово } \\
\text { сребряники, ово стеклянники, ово } \\
\text { медоковачи, ово колоколники, ово } \\
\text { печяторезцы, ово швецы, ово } \\
\text { иглопродавиыь, ово весоделатели, ово } \\
\text { скудельники, ово златотворцы, ово } \\
\text { свинцоделатели, } \\
\text { зерцалоделатели, ово кожеделатели, } \\
\text { ово красилники, ово древоделатели, } \\
\text { ово колесоделатели, ово бронники, } \\
\text { ово уздокователи, } \\
\text { корабледелатели, ово сукноткатели, } \\
\text { ово землемерители, иже земли } \\
\text { селяном деляху, ово инии мнози, иже } \\
\text { продаемые рукоделье творяху. }\end{array}$ \\
\hline
\end{tabular}

Таблица 4. Перечень троянских ремесленников и торговцев

\footnotetext{
Maslov 2019: 130-131.

Griffin 1936: 48.

$21 \quad$ LLS. Vsem. Ist. Kn. 1: 130.
} 
Как видно из сравнительной таблицы, для целого ряда латинских терминов подобраны не вполне удачные или совсем неточные эквиваленты (такие случаи выделены курсивом в латинском и древнерусском текстах - cм. le $<c>$ ticarii $\leftrightarrow$

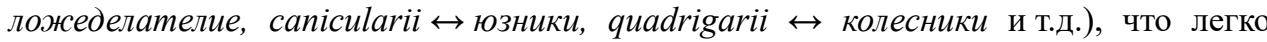
объяснить скудостью соответствующего «технического» лексикона (признаем здесь, что в отдельных случаях и значения, предложенные нами, носят гипотетический характер). Гораздо важнее, однако, что в древнерусском варианте вовсе опускаются некоторые части латинского текста (в оригинальном фрагменте они выделены подчеркиванием): таким образом, стремление к дословной передаче оригинала почему-то не распространяется на процитированный отрывок - безусловно, проблемный из-за использования редкой лексики, но крайне важный, как было подчеркнуто выше, в плане уяснения авторского замысла Гвидо.

Если следующее далее расхождение в описании реки Ксанф (в латинском тексте она делит Трою на абсолютно равные части - "diuidendo ciuitatem ipsam in geminas partes equales" 22 ; в древнерусском же «на две части разные ${ }^{23}$ ) можно объяснить ошибкой переписчика, то различия в отрывках о заселении Трои и досуге троянцев, скорее всего, свидетельствуют об игнорировании русскими книжниками тех специфических реалий античной истории, на которых делает акцент латинский писатель XIII в. Так, говоря о большом количестве новых жителей восстановленной Трои, Гвидо указывал на наличие среди них и знати, и плебеев (“[Troia] facta est nimium populosa, multis decorata nobilibus et undique tota plena in multorum incollatu uario plebeiorum" 24 ). В рассматриваемом древнерусском тексте упоминание о плебеях опущено («бысть велми народна, многими украшена благородными и от всюду исполнена населением многих разным от людей») — возможно, это слово было попросту не понято. Интересной особенностью Музейского списка является также более краткое, по сравнению с оригиналом, описание игр и зрелищ, которыми были увлечены обитатели древней Трои (На следующей странице):

Как следует из сопоставления, потенциальный читатель Музейского списка лишался сведений об изобретении троянцами театральных представлений трагедий и комедий (наряду с замечанием Гвидо о сицилийском происхождении последних), цирковых игр и майских празднеств (лат. таіита), упоминание которых в латинской «Истории» помогало подчеркнуть эрудицию автора и соотнести воображаемую городскую жизнь Трои с «подлинными» греко-римскими древностями. Хотя и нельзя утверждать, что все эти детали опущены в иных списках Древнейшей редакции, их отсутствие в рукописи XVI столетия., определенно, помогает задаться вопросом о причинах столь избирательного подхода к исходному описанию древнего города.

\section{Griffin 1936: 48.}

LLS. Vsem. Ist. Kn. 1: 130-131 (л. 620об-621).

24 Griffin 1936: 49. 


\begin{tabular}{|c|c|c|}
\hline $\begin{array}{c}\text { Латинский текст 'Historia } \\
\text { destructionis Troiae’ по } \\
\text { изданию Гриффина }\end{array}$ & $\begin{array}{c}\text { Перевод с латинского на } \\
\text { современный русский язык }\end{array}$ & $\begin{array}{c}\text { Музейский список (ОР ГИМ, } \\
\text { Музейское собрание, № 358), } \\
\text { л. 621-6210б } \\
\text { (6) }\end{array}$ \\
\hline $\begin{array}{l}\text { Huius autem ciuitatis diuersorum } \\
\text { ludorum diuersa genera diuersis in } \\
\text { ea adinuentionibus statuerunt. In } \\
\text { ipsa primo adinuenta fuerunt } \\
\text { scac }<\text { c }>\text { orum solatia curiosa, ibi } \\
\text { ludi subito irascibiles alearum, hic } \\
\text { repentina dampna et lucra } \\
\text { momentanea taxillorum. Ibi } \\
\text { tragedie et comedie dicuntur } \\
\text { primitus institute, quamuis quidam } \\
\text { asserant in insula Sicilie inuenutam } \\
\text { fuisse primitus comediam. Ibi } \\
\text { inuenti leguntur ludi circenses et } \\
\text { maiuma, que primo uidelicet ueris } \\
\text { tempore, arboribus in multa fronde } \\
\text { uirentibus et floribus in prima } \\
\text { pubescentibus iuuentute, fieri primo } \\
\text { mensis Maii consueuit. Ibi } \\
\text { multorum aliorum ludorum genera } \\
\text { adinuenta fuerunt, que } \\
\text { consueuerant hominum animos } \\
\text { demulcere et humanis aspectibus } \\
\text { solatia delectationis inger[r]ere ad } \\
\text { exillarandas intuentium uoluntates. }\end{array}$ & $\begin{array}{l}\text { Разными способами принялись } \\
\text { они устраивать в этом городе } \\
\text { всякого рода игрища. [Именно] в } \\
\text { нем впервые была изобретена } \\
\text { занимательная шахматная игра, и } \\
\text { там же }- \text { тавлея, вмиг } \\
\text { распаляющая } \\
\text { внезапной пигроков] } \\
\text { приобретением [ходов] из-за } \\
\text { [броска] кубиков. Говорят, что } \\
\text { там были впервые поставлены } \\
\text { трагедии и комедии, хотя } \\
\text { некоторые утверждают, что } \\
\text { комедию изобрели на острове } \\
\text { Сицилия. Можно прочесть, что } \\
\text { там были изобретены цирковые } \\
\text { игры и майские празднества, } \\
\text { которые обычно проводились по } \\
\text { весне, в начале мая, когда } \\
\text { обильно зеленеют деревья и } \\
\text { распускаются цветы. Там были } \\
\text { изобретены и многие другие } \\
\text { игры, имевшие обыкновение } \\
\text { утешать сердца людей и радовать } \\
\text { их, услаждая взор. }\end{array}$ & $\begin{array}{l}\text { Сего же града разных игр } \\
\text { разноличные роды разными в } \\
\text { ней обретении уставиша. Ту } \\
\text { первое обретошася шахматная } \\
\text { игра и потехи, ту игры вскоре } \\
\text { разгневимые тавлеиные, ту } \\
\text { скорые шкоты пребыти } \\
\text { внезапные зернию, яже } \\
\text { человеческия утешаху мысли и } \\
\text { человеческим зраком утехи } \\
\text { сладкие творяху веселяя } \\
\text { зрящих воли. }\end{array}$ \\
\hline
\end{tabular}

Таблица 5. Описания игр и зрелищ, изобретенных троянцами

Рассказ о сооружении по приказу Приама его собственного дворца (Илиона) ${ }^{27}$, напротив, характеризуется гораздо большей близостью к сведениям латинского оригинала ${ }^{28}$. Самыми важными отличиями видятся здесь неправильное толкование латинского pauimentum (каменный пол, вымостка) в значении «мост», а также повторяющаяся передача musaici operis (т.е. «мозаичной отделки») сочетанием «водовидное дело». Таким образом, именно в описании царской резиденции («полаты») текст Музейского списка наиболее близок к латинской «Истории».

Еще раз подчеркнем, что анализ небольшого эпизода на основе одного списка не должен подменять собой комплексное исследование всех рукописных вариантов Древнейшей редакции. Тем не менее, исходя из приведенных выше фрагментов, можно предположить, что акценты на «рациональных», «посюсторонних» элементах городской

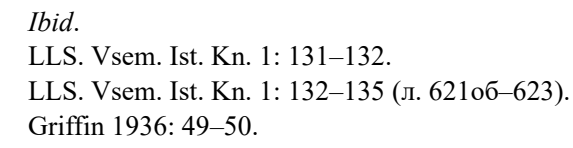


жизни в древней Трое, старательно расставлявшиеся латинским автором второй половины XIII в., отчасти приглушались в русской «царь-книге» эпохи Ивана Грозного.

Мы не рискнули бы говорить о значимости Музейского списка для компаративных штудий «урбанистического воображения», если бы не то обстоятельство, что в ЛЛС был включен еще один текст, посвященный Троянской войне - «Повесть о создании и попленении Тройском» ${ }^{29}$. Это сочинение представляет собой переработку небольшой южнославянской «Притчи о кралех» ${ }^{30}$, вошедшую в первую редакцию (1512 г.) Русского хронографа и в этой связи обретшую немалый успех среди русских читателей. В первом томе ЛЛС список «Повести» вставлен (на лл. 1003-1028об) в заключительную книгу «Истории» Гвидо - между рассказом о гибели Улисса от рук его сына Телегона (л. 1002об) и авторскими пояснениями (л. 1029 и след.) относительно источников его рассказа. Такое объединение двух произведений, посвященных Троянской войне (пусть и совсем несхожих в плане объема и содержания), возможно, показалось составителям ЛЛС, удачным композиционным решением, хотя и с трудом объяснимо сегодня.

Ключевым значением в контексте разговора об образе легендарной Трои обладает тот факт, что текст «Повести» также содержал небольшой рассказ о градостроительных занятиях Приама (следовавшего примеру своего отца Троила и его предков). Однако общая тональность этого рассказа прямо противоречила той картине созидания великой Трои, которая была явлена русскому читателю благодаря переводной «Истории» Гвидо. Приведем здесь соответствующий фрагмент «Повести» целиком: «И призва царь Приам пророки и вольхвы и рече: "Кто ми поспешит, еже еще наздати Тройский град, и аз дам ему три меры злата". И слышаста два диавола земленая, приидоста и реста царю: “Мы хощем наздати, да нам даси и наю знай”. И начаша здати. И Тебушь бе гуселник и гудяше в гусли, и зидашеся Трои, где они повелеваху, а Нептенабушь именем идяше в море и ношаше из моря вар, и камение и воду. И съвершиша все дело. И реша цареви, да им даст, еже обеща, и разумешя, яко приобиде их и разгневашеся, и рекоша: “Мы есмы сьтворили Трои град, мы умыслим, како и разорити и во дни Приамовы". И Питер вольхов, егоже пророком нарицаху, прорече, яко хощет Александр приити в греки и цароцу Елену взяти, ея же ради Трои разорится» ${ }^{31}$.

В отличие от «Истории» Гвидо, где создание великой Трои представлялось делом рук человеческих, «Повесть» оперировала несколько искаженными данными античной мифологической традиции и объясняла строительство города усилиями Феба (Тебуша) и Нептуна (Нептенабуша), представленных здесь - вполне в духе христианского толкования языческих мифов - «дьяволами земными». Еще один бог языческого пантеона - Юпитер - становится в «Повести» волхвом и пророком

29 См. о ней: Tvorogov 1972: 151-153, 162-166. Здесь же О.В. Твороговым опубликован (стр. 7-13) текст «Повести» по списку Хронографа 1512 г. (Российская национальная библиотека F.IV.178, 1538 г.) и его перевод на современный русский язык (стр. 70-77).

30 См. издание: Miklošič 1871.

31 LLS. Vsem. Ist. Kn. 2: 436-438 (л. 1006об-1007об). Cp. Tvorogov: 8. 
Питером (в исходной версии «Притчи о кралях» его предсказание было озвучено не самому Приаму, а его дочери Кассандре ${ }^{32}$ ). В целом же, перед нами - совершенно неадекватный «историзирующему» подходу Гвидо материал, который, однако, благодаря составителям ЛЛС оказался прочно ассоциирован с «Троянской историей» (по сути, включен в ее состав).

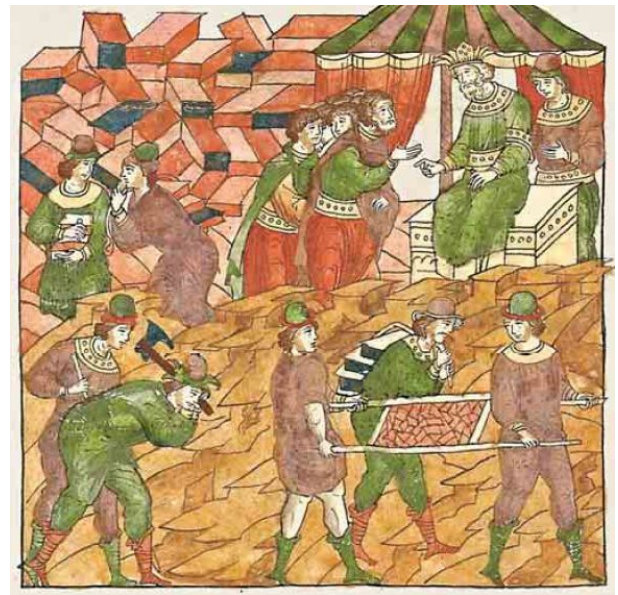

Рис. 1. Миниатюра к тексту «Троянской истории» в ЛЛС (л. 618) .

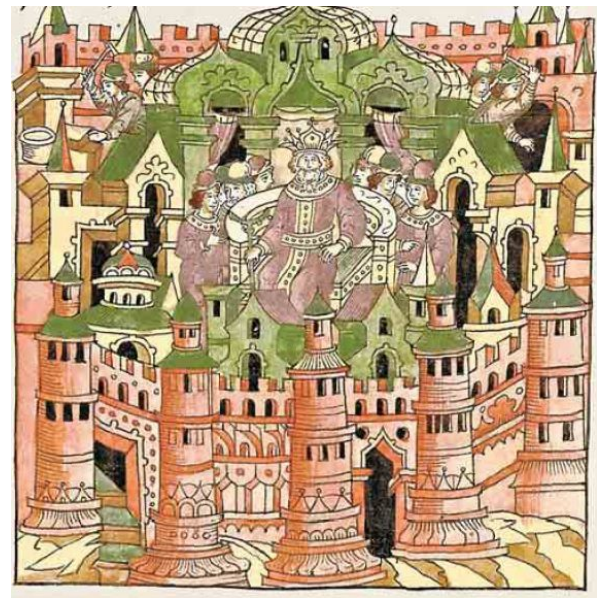

Рис. 2. Миниатюра к тексту

«Троянской истории» в ЛЛС (л. 618об).

Различия между двумя версиями происхождения Приамовой Трои нашли отражение и в иконографии ЛЛС. Если миниатюры, сопровождающие рассказ Гвидо (рис. 1-3), вполне соответствуют его рациональному взгляду на события (и буквально «населены» ремесленным людом), то иллюстрации к тексту «Повести» (рис. 4-5) выводят на первый план действия демонических персонажей. Интересной чертой миниатюр, иллюстрирующих рассказ Гвидо, оказывается и минимальный акцент на связи городского пространства с природным ландшафтом. Некоторым исключением представляется здесь изображение реки Ксанф на миниатюре л. 620 (рис. 3). Однако этот природный объект, как явно следует из текста «Истории», полностью адаптирован к структуре поселения, как бы «окультурен» в контексте рационально выстраиваемого городского пейзажа.

32 Miklošič 1871: 18-19. 


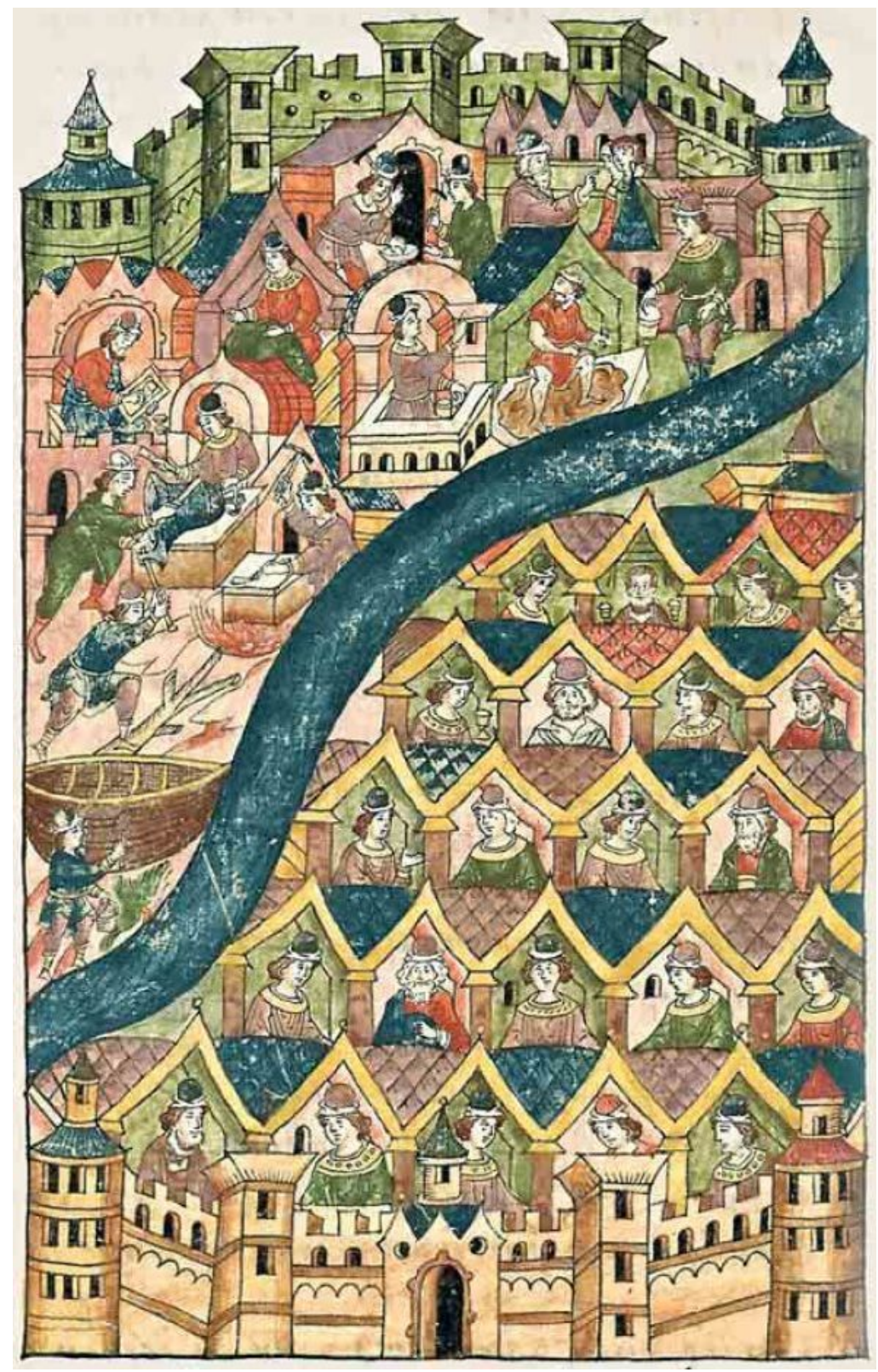

Рис. 3. Миниатюра к тексту «Троянской истории» в ЛЛС (л. 620). В верхней части изображены мастерские горожан, занятых различными ремеслами и торговлей. Изображения «типовых» домов троянцев в нижней части миниатюры позволяют передать идею унификации, рационального использования городского пространства. ${ }^{33}$

33 Ibid.: 129. 
В миниатюрах к соответствующему фрагменту «Повести» элементы природной среды (скалы, море), напротив, обозначены вполне четко, а сами эпизоды «общения» Приама с «дьяволами земными» (и «волхвом Питером» — на миниатюре л. 1007об) локализованы за пределами городских стен. В облике «дьяволов» сочетаются антропо- и зооморфные черты, в типичной для Средневековья манере эти персонажи изображены нагими и с темной кожей. Поскольку, иллюстрируя договор Тебуша и Нептенабуша с Приамом и возведение Трои (л. 1007), миниатюрист последовательно отобразил сразу несколько эпизодов легенды, парное изображение бесов повторяется здесь трижды, обеспечивая своего рода мультиплицирующий эффект и подчеркивая «дьявольский» характер стройки. Такому восприятию, должно быть, способствовало и то, что в центральной части миниатюры Нептенабуш, изображенный за строительством городской стены, держит кайло (либо сходный ударный инструмент) левой, «нечистой» рукой — в отличие от «честных» троянских тружеников, фигурирующих на миниатюрах лл. 618, 618об, 620. Отметим в качестве немаловажной детали, что на миниатюре, изображающей строительство Трои Тебушем и Нептенабушем, лица обоих бесов затерты - в соответствии с бытовавшей в древнерусской иконографии традиции «обезличивания» ${ }^{34}$, деперсонализации демонических сил, визуальное воплощение которых само по себе могло мыслиться угрозой для зрителя / читателя.

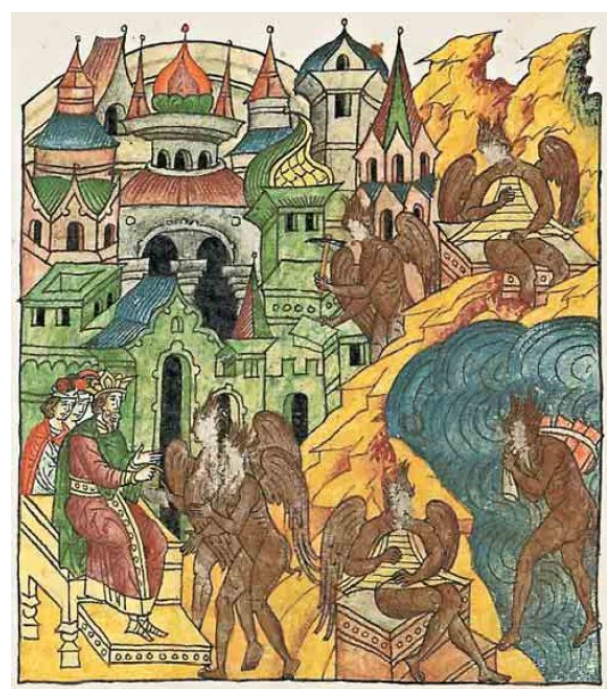

Рис. 4. Миниатюра к тексту «Повести о создании и попленении Тройском» в ЛЛС (л. 1007).

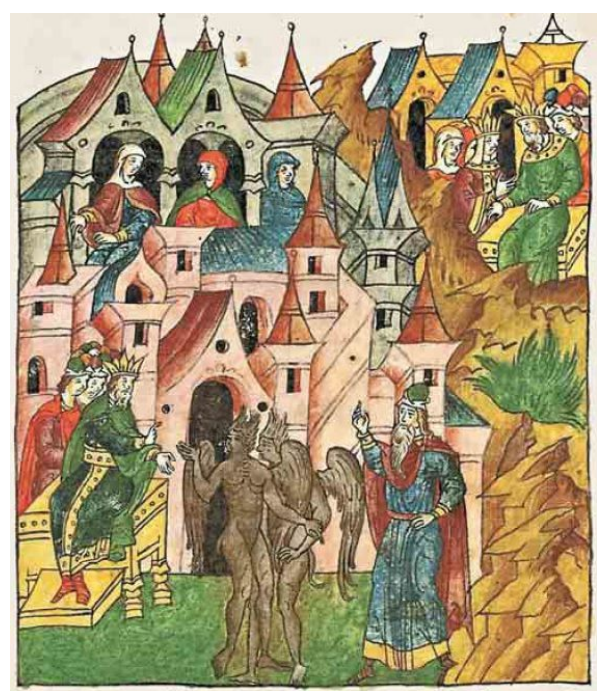

Рис. 5. Миниатюра к тексту «Повести о создании и попленении Тройском» в ЛЛС (л. 1007об). ${ }^{35}$

4 См. в этой связи Antonov, Majzul's 2011: 21-31 (esp. 24, n. 23).

35 Ibid.: 438. 
Почему в рамках одного и того же троянского раздела ЛЛС его составители посчитали возможным транслировать столь несходные картины возведения величайшего города древности? Каким образом «серьезный» и «панорамный» нарратив «Истории» оказался уравнен в правах с незатейливой и лаконичной «Повестью»? Думается, что ответ на эти вопросы хотя бы отчасти лежит в плоскости различий между восприятием книги Гвидо делле Колонне на средневековом Западе и в русских землях XVIв. Если в западноевропейской традиции популярность «Истории» Гвидо во многом определялась его склонностью к морализации и дидактизации романного материала, сближением рассказа о легендарной Троянской войне с историописанием ${ }^{36}$, то для русских книжников больший интерес представляли необычные, подчас сугубо фантастические мотивы, позволявшие представить троянское прошлое в качестве вместилища неповторимых ратных подвигов, экзотических объектов, волшебных сил и тому подобных вызовов воображению читателя. Авторские интенции латинского писателя при этом не всегда могли приниматься в расчет или даже адекватно считываться.

Эта особенность восприятия троянских легенд русской публикой ярче всего проявилась в более поздних редакциях перевода «Истории» Гвидо - по большому счету, за рамками собственно средневековой эпохи. В данной связи нельзя не процитировать фрагмент т. н. Печатной редакции (вт. пол. XVII в.), широко известной в России XVIII - начала XIX столетия благодаря многочисленным типографским изданиям. Несмотря на определенные отступления от стандартов занимательной повести ${ }^{37}$ в описание дворца Приама здесь включено такое курьезное известие: «Среди же двора оного древо некое рукотворимыя хитрости, чудне устроено бяше. Самое бо оное древо даже и до верха его, от злата чиста учинено бяше. Розги же его бяху сребрения, листвиеж такоже от злата чиста и зело тонка состроены беша зело хитре. Плод же древа того от камения драгого и бисера учинен бе. Высота же того древа лактей бяше пятьнадесять. На розгах же древа оного птицы некия различными подобии устроени беша от злата чиста, и каяждо от них свою песню хитрыми некими устроенми яко от жива языка гласа пением испущаху всех удивляюще» ${ }^{38}$. В приведенном отрывке одинаково значимы как утверждение о рукотворном происхождении «чуднаго древа» и механических птиц на его ветвях («свою песню хитрыми некими устроенми... испущаху»), так и упоминание о реакции на них посетителей Илиона («всех удивляюще»). Сицилийский судья Гвидо, работая над своей «Историей», хотел, прежде всего, поучать и вразумлять потенциальную аудиторию. Русские читатели его книги были в большей мере настроены изумляться. Насколько такое общее суждение справедливо в отношении троянского раздела ЛЛС, покажут дальнейшие исследования.

\footnotetext{
Maslov 2010: 215-216.

Tvorogov 1971: 67-69.

Istoria 1709: 71.
} 


\section{REFERENCES:}

LLS. Vsem. Ist. Kn. 1 - Litsevoj letopisnyj svod XVI veka. Vsemirnaya istoriya. Kniga 1. Istoriya razrusheniya velikoj Troi. Chast' 1, Moskva: Akteon, 2014.

[Digital version] URL: http://www.akteon-elib.ru/New_Edition/

LITsIeVOI-LIeTOPISNYI-SVOD.-Vsiemirnaia-istoriia.-Knigha-1./

LLS. Vsem. Ist. Kn. 2 - Litsevoj letopisnyj svod XVI veka. Vsemirnaya istoriya. Kniga 2. Istoriya razrusheniya velikoj Troi. Chast'2, Moskva: Akteon, 2014.

[Digital version] URL: http://www.akteon-elib.ru/New_Edition/ LITsIeVOI-LIeTOPISNYI-SVOD.-Vsiemirnaia-istoriia.-Knigha-2./

LLS. Vsem. Ist. ST - Litsevoj letopisnyj svod XVI veka. Vsemirnaya istoriya. Soprovoditel'nyj tom, Moskva: Akteon, 2014.

[Digital version] URL: http://www.akteon-elib.ru/New_Edition/

LITsIeVOI-LIeTOPISNYI-SVOD.-Vsiemirnaia-istoriia.-Soprovozhdenie./

Amosov, A. A. Litsevoj letopisnyj svod Ivana Groznogo: Kompleksnoe kodikologicheskoe issledovanie, Moskva: Editorial URSS, 1998.

Antonov, D. I. Majzul's, M. R. Demony i greshniki v drevnerusskoj ikonografii: semiotika obraza, Moskva: Indrik, 2011.

Bulanin, D. M. 'Troyanskaya tema v Zhitii Mikhaila Klopskogo', Trudy Otdela drevnerusskoj literatury, 48, 1993, 214-228.

Bushkovitch, P. 'The Trojan War at the Court of Ivan the Terrible', Russian History, 47, 2020, 36-48.

Griffin, N. E. (ed.) Guido de Columnis. Historia destructionis Troiae, Cambridge (MA): The Mediaeval Academy of America, 1936.

[Gvido de Kolumna] Istoria, $v$ nei zhe pishet o razorenii grada Troi frigijskago tsarstva, Moskva: Tipografiya Moskovskaya, 1709.

Khripkov, V. F. 'Russkie spiski i redaktsii perevoda "Troyanskoj istorii” Gvido de Kolumna', Trudy Otdela drevnerusskoj literatury, 46, 1993, 88-97.

Likhachev, D. S. Dmitriev, L. A. Alekseev, A. A. Ponyrko, N. V. (eds.) Biblioteka literatury Drevnej Rusi. Tom 8: XIV-pervaja polovina XVI veka, Sankt-Peterburg: Nauka, 2003.

Miklošič, F. (ed.) Trojanska priča: bugarski i latinski, Zagreb: D. Albrecht, 1871.

Maslov, A. N. 'K voprosu o znachenii russkikh perelozhenij “Troyanskoj istorii”' Gvido de Kolumna', Vestnik Nizhegorodskogo universiteta im. N. I. Lobachevskogo, 6, 2010, 215-221.

. 'Izobretaya ideal'noe gorodskoe prostranstvo: opisaniya drevnej Troi v dvukh srednevekovykh tekstakh', in: S. Rudić, A. A. Gordin (eds.), Urbanizacija u istočnoj i Jugoistočnoj Evropi, Beograd: Istorijski institut, 2019, 117-136.

Morozov, V. V. Litsevoj svod v kontekste otechestvennogo letopisaniya XVI veka, Moskva: Indrik, 2005.

Serova, I. Yu. "Letopisnaya kniga” I. M. Katyreva-Rostovskogo i "Troyanskaya istoriya" Gvido de Kolumna', Trudy Otdela drevnerusskoj literatury, 42, 1989, 107-114.

Shmidt, S. O. (ed.), Belokon', E. A., Morozov, V. V., Morozov, S. A. Litsevoj letopisnyj svod XVI veka: Metodika opisaniya $i$ izucheniya razroznennogo letopisnogo kompleksa, Moskva: Izdatel'stvo RGGU, 2003.

Tvorogov, O. V. 'Drevnerusskij perevod “Troyanskoj istorii” Gvido de Kolumna i izdanie 1709 g.', Trudy Otdela drevnerusskoj literatury, 26, 1971, 64-71.

. (ed.) Troyanskie skazaniya: Srednevekovye rytsarskie romany o Troyanskoj vojne po russkim rukopisyam XVI-XVII vekov, Leningrad: Nauka, 1972.

Volkova, T. F. 'K izucheniyu pechorskikh spiskov Troyanskikh skazanij (dve redaktsii I. S. Myandina)', Trudy Otdela drevnerusskoj literatury, 55, 2004, 394-414. 


\author{
ARTEM MASLOV \\ Lobachevsky State University of Nizhny Novgorod \\ Department of Ancient and Medieval History
TSAR PRIAM'S CITY AND THE RUSSIAN 'TSAR BOOK': DESCRIPTIONS OF THE ANCIENT TROY IN THE 'ILLUSTRATED CHRONICLE COMPILATION OF IVAN THE TERRIBLE'

\begin{abstract}
Summary
This article continues the series on representations of the ancient urban spaces in the medieval literary tradition and deals with the analysis of two fragments of the 'Illustrated Chronicle Compilation of Ivan the Terrible' ('Litsevoj letopisnyj svod Ivana Groznogo', below - LLS), which describe the construction of the legendary Troy by the order of King (or, in Russian, Tsar) Priam. The first of these descriptions is included in the Old Russian translation of the 'History of the Destruction of Troy' by Guido delle Colonne (Guido de Columna) and covers in detail the external and internal features of the ancient city, the specifics of its settlement and the occupations of the citizens. Such a 'rational' approach, that is associated with the didactic elements of Guido's Latin 'History' and partly preserved in the Old Russian tradition, contradicts the picture of the construction of Troy, which is contained in the second (as part of the $L L S$ ) work on the matter of Troy, that is the so called 'Povest' o sozdanii i poplenenii Trojskom' ('Tale of the Creation and Captivity of Troy'). The latter is an adopted version of the South Slavic 'Pritcha o Kralekh' and, unlike Guido's 'History', is characterized by an emphasis on the mythological (or even demonic, according to the Christian interpretation of this episode) origins of Priam's Troy. In the light of Guido's scholar reputation among western readers it seems strange that his 'History' was combined with the 'Povest" within the $L L S$. The duality of such a view on Troy origins shaped by this textual combination is considered by the author in the context of the medieval reception of Trojan legends in Western and Eastern Europe. Special attention is paid to miniatures, which illustrate the episodes of Troy foundation in the $L L S$ and include a number of visual codes that possibly influenced the reader's perception of the images.

Keywords: images of Troy in medieval tradition, 'Historia destructionis Troiae' by Guido delle Colonne (Guido de Columna), Old Russian translation, 'Illustrated Chronicle Compilation of Ivan the Terrible', 'Povest' o sozdanii i poplenenii Trojskom'.
\end{abstract}

(C) Faculty of Philosophy, Novi Sad, 2021

ISTRAŽIVANJA - JOURNAL OF HISTORICAL RESEARCHES 32, 100-115 